\title{
Political economy of the Kenyan media - towards a culture of active citizen journalism
}

\author{
Fredrick Ogenga
}

\begin{abstract}
This paper utilises Hall's (1977) 'encoding-decoding' theory in the context of critical political economy theories of the media and cultural studies to explain the political, economic and cultural factors that influence media operation and content both at a macro and micro level. While political economy provides the setting in which the Kenyan media operates, cultural studies show how media content is not only shaped by the political and economic environments comprising those in power positions. Audiences are also actively engaged in the process of meaning construction. Considering Hall's (1977) encoding-decoding theory, the audiences can reject, negotiate or accept media content based on their own value systems and cultural orientation. Meaning, therefore, becomes a product of continual struggle between different discourses and power cannot be located in a top down manner as to who influences meaning as seen in a propaganda model. This is due to the fact that texts are diffused in different locations in society. The 2008 Kenya Communication Bill is utilised as an example to trace briefly the political and historical developments of policy issues that have influenced the Kenyan media. The Bill, furthermore, indicates how a weak socio-economic, political and cultural environment is marred by ineffectual policies meant to safeguard and guarantee the freedom of the press as an extension of individual freedom of expression as enshrined in the Kenyan constitution. This weak policy context has ensured the Kenyan media remains subject to easy political manipulation and control. However, the paper concludes by showing how citizen journalism is growing out of a regulated mainstream media through internet technology.
\end{abstract}

\section{Key words}

citizen journalism, critical political, Communications Bill, cultural studies, economy of the media, ideology, internet blogging.

\section{Introduction}

This paper begins by identifying the role of the media in liberal democracies within a sociopolitical, economic and cultural framework: factors that shape media operation in Kenya. 
Issues such as media ownership and political factors influence media content and the manner in which the Kenyan media operates both at a macro and micro levels.

At a macro level, political factors include media ownership and control. Here political leaders, through their privileged position, manipulate content through funding, using their privileged position as official sources and imposing media regulation, censorship and legislation

At a micro level, the critical political economy of the media includes ideologies of journalism and various professional routines and work practices that inform the daily recycling of commercial news content on the one hand. On the other hand there are investigative journalistic practices, as well as the media fulfilling a watchdog role in a liberal democracy to safeguard against a return to an authoritarian influence and as a condition for its very legitimacy.

The paper later departs from the question of how the media operates,and the content therein, and moves to audience responses and their power and ability to influence and shape the very same content - content that is being mediated, as opposed to, a top down classical Marxist ideological approach of political influence exercised by political leaders, especially those that form the government of the day.

The paper, therefore, recognises the complexity in defining a relationship holistically and solely influenced and determined by political and economic factors. The paper thus introduces the idea of culture and the struggle for meaning in public space (the media) through hegemony and negotiated consent. However, the paper agrees that hegemony is a product emanating from heavy contestation of different ideas. The media should therefore be considered as the arena that creates a platform for debate on different socio-economic and political thoughts. It should thus operate freely and represent this diversity of thought. If the media succeeds in doing so, then it is a move towards democratic advancement.

However, due to the power of politicians, emanating especially, from a colonial institution, the media is often threatened, censored and gagged in the name of national interest or state security or even cultural values. This appears to be the case in Kenya. In such a situation then, the citizens/audiences find alternative arenas such as the internet to debate contentious issues of public interest. The search for a free public space for freely expressing their thought can increase an active participation in what has now been known as citizen journalism considering that the mainstream media is owned and controlled by few people who have privileged access to the mainstream media, are in power positions and have the material capabilities of controlling cultural capital. The paper concludes by suggesting how the increasing growth of internet blogging could be a product of a societal struggle in the construction and mediation of political, social and economic and cultural experiences in Kenya through the media in an attempt to understand or come into terms with reality. 


\section{The media in liberal democracies}

The media in liberal democratic countries acts as a watchdog and a custodian of human rights as a condition for its very existence. Liberal democracy thus implies a low degree of political control of the media and a high degree of tolerance among political elites for the unwelcome and critical things which journalists in such systems will write and say. A liberal democratic political system demands journalistic criticism of elites as a condition of its legitimacy. Critical and pluralistic journalism is viewed as a safeguard against the possibility of a return to the authoritarian rule and as a watchdog against the abuse of political power (McNair, 1998 :83) and ( Ogenga, 2008). The Kenyan media is assumed to operate under liberal democracy.

Political system largely determines the political culture. Considering the Kenyan context, critical political economy of the media indicates that the media, under a liberal democratic arrangement, has some degree of autonomy and freedom to report and even criticize the government but still identifies certain authoritarian tendencies that prevail through censorship and control (McNair 1998). Political factors include the power of government officials to manipulate and exercise control over journalists through censorship and media regulation in a given occasion in order to safeguard national interest or national security, and sometimes selfish political interests. Journalists are supposed to hold politicians accountable for their actions and expose corruption.

Leftist critics of liberal democratic political systems, however, see the freedom to attack the ruling class as opposed to being symbolic and employing superficial attacks on the management of capitalism, which, by removing the rotten apples from the barrels, ultimately serves to strengthen the system and its inherent inequalities (McNair 1998). Journalists have an economic relationship with the state, this is in cases where the political apparatus has control over sources which can be employed as a means of exercising pressure.

Although the Kenyan media can be said to have a legacy of colonial inheritance, like many other media in Africa (see Kariithi 1994), it has been structured along the western commercial model. The argument is that the Kenyan media, due to its structure, operates as a commercial industry in the business of manufacturing content with a user value that can appeal to the target market,

McChesney (2003) and Williams (2003) argue that Economic factors/ market forces impact on the media in ways in which it becomes an industry. The media therefore operates as an economic institution in the business of cultural production. Journalists come up with news stories that will encourage readership and therefore sell the readers to advertisers. In a sense, media owners are in a position to control the kind of news stories that will appeal to their readers interests and at the same time not offend advertisers. This can sometimes lead to sacrificing journalistic freedom, creativity and integrity at the altar of owners and advertisers 
who exert a major influence in the content. Journalists for instance, cannot afford to give negative publicity to their advertisers.

Considering the discussion above on market forces, suffice it to argue that in Kenya politics are considered newsworthy and often politicians who scoop the lions share as sources in news stories are relied upon by journalists when covering events leading to some form of framing and stereotypical representation of issues. Of course the more credible the source, the more likely the source will be utilised in the process of news construction.

\section{Political economy of the media}

This involves the idea of media ownership, the media market and financial support. The manner in which the media operates is shaped by their owners, the market environment and the financial support. In this environment, the media manufactures cultural content that sustains the system 'capitalism' (see Curran, 2000b; Chomsky, 2003). The media is in the business of maximize profits just like any other business organization in capitalism (Williams, 2003; Mc Chesney, 2003; Mosco, 1996; Hesmondhalgh, 2007).

Central to this argument is the idea that the product or the content of the media may be shaped by corporate interests, basically, interest of the owners. Media owners ensure they appoint journalists who share the same ideologies as theirs in the market driven system into managerial position to sustain their interests and the interests of a particular class (Ramaphosa, 1999). News and investigative reports that journalists produce have a value attached to it for maximizing profits (Chambers, 2000). The media is thus obliged to meet the needs of owners, the audiences; advertisers as well as media employees by employing a delicate balance between these stakeholders (Picard, 1989). This obligations influence media content (Gandy, 1997).

Mbeke (2008) argues that the Kenyan media has never been in a comfortable position with regard to the political, economic, technological and social environment. Often the media environment has been politicised and little has been done in terms of policy to address issues that could lead to a stable, independent and critical media. The media environment has been volatile, one that gives room for the bullying and gagging of the media whenever the media strives to function as a watchdog in exposing government scandals and other issues of public interest.

In Kenya, like many other media outlets in Africa, the government, for instance, owns the Kenya Broadcasting Corporation in terms of public broadcasting. There is also a good number of private ownership of the media especially through the dominant Nation Media Group. But is this all we need? The political and economic environment in which the Kenyan media operates therefore possibly influences the manner in which the Kenyan media operates. Unravelling agendas and competing interest in this political and economic environment can give insight into understanding how the Kenyan media operates for policy proposals on how it can be transformed. This environment demands that the media conforms to pressures from politicians on one hand and the audiences and advertisers on the other. The 
environment is characterised by friction that can sometimes lead to framing, propaganda and distorted representations. This kind of distorted representation raises theoretical concerns in the idea of realities and meaning in the minds of the Kenyan audience.

\section{What do such kinds of media representations mean to the Kenyan audience?}

The encoding - decoding model (Hall 1977) in cultural studies indicates how audiences can reject the content of the media and come up with an oppositional, resistant or negotiated response when decoding or receiving media content. As a structuralist, Hall argues that audiences contribute in the production of meaning and will decode media messages based on their own socio-cultural and economic contexts that shape their realities. Although the media has the capacity to build consent from a hegemonic perspective, this consent is struggled and fought for by the ruling class to ensure that the existing or prevailing social relations are maintained. In the crisis of hegemony, Gramsci argues that force becomes a last resort to win the consent of the proletariat. However, as we shall later see in this Kenyan case, the citizens are fighting back through the very same tool that is being censored by engaging into citizen journalism through internet blogging. In addition technological traits and developments in media are increasingly being seen to influence traditional mainstream journalism, a factor that poses a new challenge to the mainstream media if not the government. How then can the government regulate internet users and blogging for instance and make sure their regulation is practical? This is another thesis in itself and beyond the scope of this paper. If this seems to be the case in Kenya though, why contest the media?

\section{Contesting the media in Kenya.}

Jurgen Habermas in Fraser (1992) highlights how the media is a constant arena of battle in democracy by the elite because of the significant influence that it has in representing meaning and ideologies. Economic power from a classical Marxist perspective, takes on the power to control and shape reality through mediated ideas. Althusser (1971) and Gramsci (1971) have viewed the media as ideological state apparatuses and recognise their influence in building hegemony and spreading ideology. In the reigns of Lenin and Hitler, when technology and modernisation was improving, the concept of mass society was born. Mass society was considered a threat to closed conservative societies because the mass exercised enorrmous influence into public opinion and threatened the existence of the state by breaking down the structures of a closed society into a sort of global culture commonly referred to as mass culture.

From a Karl Marx perspective in the 1970s the concept of mass, a culture of consumption, was capitalised in terms of advertising content, circulation and sales and the media played a big role in popularising certain capitalistic needs based on commodities and assets and the means to satisfy those needs through creating demand for the commodities and the assets. Ultimately, the popularisation of needs including false needs in capitalism by the media was to make profits and sustain capitalism- a system that ensures the media continues to make profits: and words such as ‘fetishism' were born.

However, from a cultural studies approach, the audiences still remain intelligent, as Hall 1977 explains, and are always critical of whatever content they receive from the media. Audiences are increasingly involved in the process of media representation by the manner in which they 
decode various meaning from any media content. Furthermore modern media technologies like the internet give room for immediate feedback and interactivity which broaden the scope and quality of debates about challenging issues that citizens are faced with such as poor governance, corruption, crime, HIV/AIDS and hunger.

If media owners on one hand exert some degree of control and influence to the media and the content, ensuring that the media largely reproduce their ideas, as explained through political economy and the audiences on the other hand are intelligent enough to reject such contents or give them a variety of readings within the cultural study context, why then did the Kenyan media Amend the Kenyan communications Bill?

At this point, it is important to look at the circumstances that led to the Amendments:

1. An election crisis in 2007 that ensured a state of emergency was declared on the media due to its extensive coverage of the entire process and the controversial results

2. A critical media in 2008 that exposed members of parliament as fat cats and big spenders who refused to pay taxes and did not care about their constituents.

3. A robust coverage of the civil society activities such as human rights and other groups, and the controversial debates on extrajudicial killings later evidenced through the deaths of the Director of the Oscar Foundation Kamau Kingara and programme coordinator Paul Oulo.

All the three points seem to be excellent in terms of how the media in any democracy has to operate, critical of the activities of the state as a condition of its legitimacy. Why then is the Kenyan media loosing independence and appears to be very vulnerable and cannot stand its ground in the midst of such excellent coverage?

\section{Policy setbacks}

In retrospect, the Kenyan media has suffered setbacks in term of various acts of parliament and amendments based on the socio-economic and political context of particular eras of its existence. For example historically, the Kenyan media during the Kenyatta era (1962-1978) was highly monitored and the factors that shaped media law and policy included the urgent need for national unity and development, political rivalry and ideological issues surrounding media ownership. The independent government was intolerant towards the press and enacted the Official Secrets Act in 1968 to deal with a series of leaks that made the government vulnerable to political pressure (Mbeke, 2008).

Amongst the issues that influenced president Moi’s attitude (1978-2002) towards the media was the attempted 1982 military coup, economic recession that led to international monetary Fund structural Adjustment programmes and popular agitation for economic and political liberalisation and globalisation. However, these forces were too powerful for Moi's government to contain leading to further Amendments that led to greater liberalisation.

Kibaki’s administration (2003-2008) had a difficult relationship with an independent, assertive and watchful media in Kenya: for instance the media exposure of Anglo leasing 
scandal, low public rating, a hostile media and a formidable Orange Democratic Movement opposition. Kibaki's government succumbed to pressure and changed tack towards the media (Mbeke 2008) creating the Media Council of Kenya for the conduct and discipline of journalists and the media as a mechanism to provide self regulation of the media. The Council was financed by the government and the members appointed by the government. In other words, Kibaki created a control mechanism underscoring the political economy argument and the capacity of politicians to exercise influence and control of the media through state machinery as McNairs 1998 indicates.

The Media Council of Kenya was responsible for the banning of all live broadcasting during the flawed election results in 2007and formed a task force to investigate the conduct of the media during elections (Mbeke 2008). It is important to note that although the government seemed to have been tolerant of the Kenyan media in the recent past it has undermined development in some media forms, for example: the reluctance to support the development of community media and broadcast in vernacular languages because of its fear of empowering citizens in a way that would challenge its hold on power and demand good governance (Mbeke 2008) thus denying Kenyans the crucial recipe for an ideal democracy - pluralism and lingual multiplicity - to embrace the spirit of Kenya as a nation.

Embarking on Mc Nair's (1998) arguments, that under a liberal democratic arrangement, while the media has some degree of autonomy and freedom to report and even criticize the government in liberal democracies, there are still certain authoritarian tendencies which can be identified that prevail through censorship and control (McNair 1998). This can be done through various amendments and laws that curtail freedom of expression such as what the Kenyan government did recently. Consequently, there are political forces that have emerged in Kenya and are now shaping the environment in which the Kenyan media is operating through the Kenya Communications Amendment Bill 2008 and the Kenya Communication Amendment Act 2008, assented to by president Kibaki. These will go a long way in influencing the content of the media for as long as it remains an Act of parliament. However there is some hope with proposals to amend it through the consultations of various stakeholders including media professionals and human rights groups.

\section{What is contentious about this Bill?}

An item on the BBC news Friday 2 January 2009 answers the question with a piece entitled: Kenyan President Mwai Kibaki has signed into law a media bill that journalists say will curtail press freedom.

By creating the space for the minister of communications to issue future policy guidelines to the Commission on issues of a general nature related to the provision of this act, the Kenyan government has created a powerful mechanism for manipulating the media given the politics of political patronage that have since plagued the Kenyan government. The Bill can thus be manipulated by political interest group for the purpose of pursuing selfish political interests considering that the object and purpose for which the commission is established is to 'license' and 'regulate' postal information and communication services in accordance with the 
provision of this act. This act, furthermore, contradicts itself in the new sections that are inserted under section 5 as $5 \mathrm{~B}$ which state that 'Except as provided for under this Act or any other law, the commission shall exercise its functions independently of any person or body'. Of course this is not practical in Kenya for reasons that I have just mentioned above. The inclusion of yet another contradictory Amendment of section 6 states that 'at least seven other persons, not public officers appointed by the minister, shall form part of the commission however the minister will still have power regarding these seven representatives'. Clearly there is much power vested in the minister, and naturally absolute power, especially considering that the law gives the Kenyan authorities the power to raid media offices, tap phones and control broadcast content on the grounds of providing national security. The Kenyan Communications Amendment Bill gives the state power to raid media houses and control broadcast content. Justifying McNair's 1998 argument on state censorship president Kibaki defended the Bill by stating that regulating the electronic media would promote and "safeguard our culture, moral values and nationhood". There is no doubt and as McNair 1998 observes that this is a perfect example of the authoritarian tendencies that are still visible even in liberal democracy that curtail freedom of expression. Although the Kenyan government has insisted that it is committed to press freedom, the countries' media has feared for its independence since a 2006 raid on a TV station and newspaper offices.

\section{So, what next?}

Theoretically the argument is that any attempt to use national security of the state or national interest or moral values and nationhood to make it difficult for citizens to receive or impart information in terms of freedom of expression amounts to censorship no matter how much the benefits of such a move might outweigh the losses. This is according to structuralists; constructionists like McNair (1998); Williams, ( 2003).

However contentious the Bill might seem, the truth is that it is now law. Although the move might be seen as a way of censoring the media and therefore limiting discourses around socio-economic and political challenges facing the country. It might have just opened another public sphere, 'public space' for debating the very same issues through improved internet technology like blogging, mixit and facebook. Although we hardly come across heavy criticisms and hard hitting factual questions directed to our leaders by journalists through traditional mainstream media like $\mathrm{TV}$, radio and print, the online publications are doing it through citizens.

The citizens are increasingly developing a brand of journalism through internet blogging to debate issues among themselves, since politicians seem to be beyond their reach through mainstream channels. Harbermus in Fraser 1992 claims that real freedom and democracy demands a free press and plurality of thought and the internet has created a space for such pluralism. The 2008 Kenya Communications (Amendment) Bill is surely pushing even more

Kenyan citizens to actively become critical journalists, little wonder at the height of the post election violence internet bloggers in Kenya kept the world informed.

Conclusively, private companies and individuals should continue investing in ICT, taking advantage of government subsidies on computer technology to ensure more people, especially in the rural areas, are connected. The long-awaited SEACOM and the East African 
Marine System (TEAMS) fibre optic undersea cable that has officially been launched in Kenya is a commendable move. The 5,000-kilometer TEAMS cable, for instance which starts in Fujairah, UAE, and runs to Kenya under the Indian Ocean, is expected to cut telecommunications costs across the continent and make it easy to invest not only in the information business, but cut down logistical and research costs among small, medium and big companies .

The government should also review sections of the Communication Bill that challenge freedom of expression and amend them, the government must also come up with better policies concerning media ownership and change colonial inherited policies in the media industry that have got no significance given the current socio-economic and political dynamics. The government must create a favourable environment to attract investments in communications and media technology. It must promote community media especially radio broadcasting to empower citizens who in turn will make them more accountable. Most importantly, it must give room for plurality of ideas through encouraging media diversity and encouraging active participation in civil and other human rights societies. It should exercise some degree of responsibility in terms of regulating the media by including media owners and representatives when formulating such agendas. It must therefore come up with policies and laws that respect the rights to freedom of expression and promote diversity through non discriminatory languages. Most of these issues are presumed to be addressed in the new constitution.

\section{Appendix 1 \\ Citizen Journalism}

Refer to the following excerpt from Kenyan bloggers about the Media Bill and the perception of an intelligent audience which does not always necessarily agree with everything the media says as Hall (1977) indicates:

http://bankelele.blogspot.com/2009/01/media-bill-2008.html

“...Can we focus on specific issues in a constructive manner? What are the pros and cons of this bill and how do they measure up against each other?”

"What exactly is objectionable in the Communications Amendment bill? Why is it objectionable? Does it invalidate all other benefits of the bill? What is the proposed alternative?”

$$
\text { 1/03/2009 6:32 PM }
$$

MainaT said...

"Good summary. You missed out opening of letters by Posta which they can do without specific pretixt.

“ Its a very poorly drafted law with many parts colliding or mixing others.

Sec88 is now reality-btw, it initially didn't include broadcasting equipment. All because 
Poghisio was annoyed by coverage relating to the allowances he over-ate. My understanding is that he and media had actually gone thru a draft in which he was to delete sec88 or parts of it. Majorly, the bill requires editing. Also if CCK is going to have those overarching powers, it might be prudent to have media representation.”

\section{1/03/2009 6:39 PM}

KE said...

"I've long ago dissuaded myself of the notion that laws in Kenya mean anything. Why did the MP's even bother 'changing' the law when they can already get away with whatever they want:

- Lucy slaps a reporter (battery) and gets away with it

- Michuki raids a media house and destroys their equipment (vandalism) and gets away with it.

- Cholomdely kills 2 people and Amos Wako pretends to prosecute him. Does anyone believe he'll spend any significant time in jail?

"The truth of the matter is, if you have enough money and power in Kenya, you can operate above the law. We all need to stop fooling ourselves about Kenya being a law abiding state.”

kenyanentrepreneur.com

1/04/2009 1:56 AM

Maishinski said...

@KE

“Exactly! I could not have put it any better myself. The so-called 'Media Freedom' is an illusion and has never existed since independence. There was no media bill when Lucy, Michuki and Arturs raided the media - with IMPUNITY.

"And the damage was great - including assault. Did they face justice? Was any one of them 'demoted'? Was there any consequence for their actions? Was there any press freedom then? In Moi days (and laws haven't changed) police could seize and destroy equipment etc. Kibaki has the same powers and can use them any time - Media bill or not! The media should stop CHEATING Kenyans about what is really happening on the ground. Our leaders and those connected to them are generally 'above the law'.

"All the AG has to do is issue a nulle prosequi and that's it - case closed! As long as cops can arrest you on the streets and lock you up for 'loitering', as long as colonial laws still govern us, as long as executive powers are vested in one or two individuals we cannot claim to be free!

"We need to ask tough questions and seek some painful answers. How did the bill get to the president? Who passed the bill in Parliament? Isn't it the same tax evading thugs raving at the President? Aren't the MPs really just as guilty as Prezzo for betraying Kenyans (if that is 
really what has happened) by failing to exercise due diligence in their work?

"Now the dumb sheep will follow their shepherds and start protesting loudly for NOTHING

(really) bringing further shame to our country. Ninety percent of those to be tear-gassed in the streets will not have read the bill (let alone analysed it rationally).

"If you were to stop a protester and ask them to specifically say what the issue is, why they are on the streets and how it can be addressed you will get the dumbest responses on this planet. Then you realise that the poor morons don't even read the papers and are, in fact, just venting about NJAA (hunger) rather than media bill.

"Consequences: External parties will see political instability... economic recovery is delayed further as investors review their position... inflation continues... food shortage.. Fast forward... May 1, 2009 - Labor day: PM walks to the dais and the same stupid sheep (now more hungry than ever) start chanting UNGA! UNGA! UNGA!

Seriously.how dumb can people get?”

1/04/2009 8:39 AM

\section{About the author}

Author: Fredrick Ogenga

Title: The author is currently a media consultant and analyst. He has a bachelors and a masters degree in Media \& Journalism studies. He is also a freelance writer, a reporter for africanews.com, a lecturer in Media \& Journalism and the founding director of Tazama Media Consultants closed corporate company. He is pursuing a PHD in media studies at the University of Witwatersrand.

Email address: braco_od@yahoo.com

Physical address: 48 Dekorte \& Station street, Braamfontein, Johannesburg. South Africa.

Cell: +27 (0) 760153549

Author's personal web page: www.tazamamediaconsultants.blogspot.com

\section{References}

Althusser, L. 1971 'Ideology and ideological state apparatuses', in Lenin and philosophy and other essays (eds). London: New Left Books

Chomsky, N. 2003.Undersatnding power: the indispensable Chomsky. London: Vinatge

Curran, J. 2000b. Rethinking media and democracy’. In Curran, J. \& Gurevitch, M. (eds.) Mass media and society. London: Arnold, 120-152 
Chambers, D. 2000. Critical approaches to the media: The changing context of investigative journalism. In De Burgh, H. (ed.), Investigative journalism: context and practice. London: Routlegde, 89-107

Gandy, O.H. 1997. The political economy approach: a critical challenge. In Golding, P. \& Murdock, G. (eds.), The political economy of the media Volume1.UK: Edward Elgar Publishing Limited, 87-106

Gramsci, A. 1971. The prison notebooks. London: Lawrence and Wishart

Hall, S. 1977. Culture, the media and ideological effects In Curran, J., Gurevitch, M., \& Wollacott, J. (eds). Mass communication and society. London: Edward.

Hesmondhalgh, D. 2007. The cultural industries. $2^{\text {nd }}$ ed. London: Sage

Kariithi, N. 1994. The crisis facing developing journalism in Africa. In Media development. 4: 28-30

Legum, C. 1971. The Mass Media-Institutions of the African Political Systems. In Stokke, O. (ed.). Reporting Africa in African international mass media. Uppsala: The Scandinavian Institute of African Studies: 27-38

McChesney, R. 2000. Rich media, poor democracy: communication politics in dubious times. New York: The New Press

Mbeke, P. O. 2008. The media, legal, regulatory and policy environment in Kenya.. A historical briefing. School of Journalism and Mass Communication. University of Nairobi Kenya

McNair, B. 1998. The sociology of journalism. London: Arnold

Mosco, V. 1996. The political economy of communication. rethinking and renewal. London: Sage

Nancy, F.1992. Rethinking the public sphere: a contribution to the critique of actually existing democracy . In Habermas and the public sphere (Craig Calhoun, ed.). Cambridge, MA: MIT Press. 109-142.

Ogenga, F. 2008. The role of the Kenyan media in the 2007 elections. EISA Journal of African Election. Vol 7 (2)

Picard, R.G. 1989. Media economics: concepts and issues. Newbury Park: Sage

Ramaphosa, C. 1999. The Media, the editors and the owners in Financial Times 14-05-1999: 20-21

Williams, K. 2003. Understanding media theory. London. Arnold.

http://bankelele.blogspot.com/2009/01/media-bill-2008.html

www.bbcnews.com

http://www.eastandard.net/downloads/kca_act_2008.pdf 